\title{
Plain Packaging and Pictorial Warning in Asia Countries: Where are We?
}

\author{
Kavita-Jetly, ${ }^{1,2}$ Azmawati Mohammed Nawi, ${ }^{1}{ }^{*}$ Qistina Mohd Ghazali, ${ }^{1}$ and Mohd Rizal Abdul Manaf ${ }^{1}$ \\ ${ }^{1}$ Department of Community Health, Faculty of Medicine, Universiti Kebangsaan, Malaysia, Cheras, Malaysia. \\ ${ }^{2}$ Ministry of Health Malaysia, Federal Government Adminis trative Centre, 62000 Putrajaya.
}

*For reprint and all correspondence: Assoc. Prof. Dr Azmawati Mohammed.Nawi, Department of Community Health, Faculty of Medicine, Universiti Kebangsaan Malaysia, Jalan Yaacob Latif, Bandar Tun Razak, 56000 Cheras, Kuala Lumpur, Malaysia.

Email:azmawati@ppukm.ukm.edu.my

\begin{abstract}
Worldwide, around 8 million people die yearly due to tobacco usage. Cigarettes moking is the most popular form of tobacco usage. Smoking has linked to many detrimental health effects among adults and adolescents. Recognising the burden of s moking, World Health Organization have implemented various tobacco control strategies under the Framework Convention of Tobacco Control and mPOWER. This includes implementation of plain packaging and pictorial warning. In Asia, only Thailand, Singapore, Turkey, Saudi Arabia, and Israel have implemented plain cigarette pack. However, s ome countries have made progress to implement plain cigarette pack. Although some countries have not implemented plain pack, implementation of larger pictorial warning serve as a pathway for implementation of plain packaging. Countries with pictorial warning on cigarette pack should ensure it covers at least $50 \%$ of pack. Timor Leste has the largest pictorial warning on cigarettepack in the world. In conclusion, only 5 countries in As ia have implemented plain pack and some countries in this region are yet to implement size of pictorial warning according to requirement of World Health Organization. All countries should target to implement standardized pack to denormalise tobaccousage.

Keywords Tobacco-Plain packaging-Cigarette-Asia - pictorialwarning.
\end{abstract}

Article history

Received: 17 December 2021

Accepted: 24February 2022

Published: 1 March 2022 


\section{INTRODUCTION}

One of the most preventable cause of death is dis eases caused by tobacco usage. ${ }^{1,2}$ About 1 in 5 adults worldwide smoke tobacco. Smoking cigarette is the most popular form of usage of tobacco use worldwide. ${ }^{1}$ Other formof usage of tobacco includes waterpipe tobacco, smokeless tobacco products, cigars, cigarillos, roll-your-own tobacco, pipe tobacco, bidis and kreteks. Despite how tobacco is used, its usage causes addiction and detrimental health effects. ${ }^{2,3}$ In general, smoking damages nearly every organ of the body, causes many dis eases, and impairs the health of smokers. ${ }^{4}$ The usage of tobacco is linked to many adverse health effects such as heart disease, stroke, cardiovascular dis ease, respiratory dis ease, and cancer. ${ }^{4}$ Tobacco use is among adolescence linked to other high risk behavior which includes bullying, early and unprotected sex, poor life satis faction, high levels of alcohol consumption and violence. ${ }^{5,6}$ Some studies have linked smoking to drug abuse..$^{7,8}$

Recognizing the burden of tobacco usage, World Health Organization (WHO) have implemented various tobacco control strategies under the Framework Convention of Tobacco Control (FCTC). ${ }^{9} \quad$ FCTC uses evidenced-based findings to ensures all people receive the highest standard of health. The convention came into force on 27 February 2005 and currently there are 182 countries in this convention which includes more than $90 \%$ of the world population. ${ }^{10}$ The main aim of this convention is to protect current and future generation from the detrimental outcomes of tobaccouse in the scope of health, social, economic and environment. ${ }^{11} \mathrm{mPOWER}$ was introduced by WHO in 2008 which was in line with WHOFCTC. ${ }^{12}$ FCTC have proposed the implementation of plain packaging and pictorial warning, however the strategies of mPOWER focus ing on implementation of pictorial warning. ${ }^{13-15}$

There are many studies which has been done which indicates the effectiveness of plain pack and pictorial warning. According to $\mathrm{WHO}$, plain pack acts to reduce the appeal of tobacco products and increases the visibility and effectiveness of health warning. ${ }^{15}$ Plain packaging increases negative feelings of non-smokers to initiate smoking and among smokers, motivates quit attempts and reduces consumption. ${ }^{16,17}$ This can be attributed to the unattractive colour of plain pack and removal of branding on plain pack. In a study done in Thailand, the unattractive colour of plain pack of dark olive evoked feelings of not wanting to buy plain cigarette pack. ${ }^{18}$ This was enforced by absence of branding which makes the packaging unattractive.

Plain packaging and pictorial warning independently and synergis tically acts alter smoking behaviour among non-smokers. ${ }^{19}$ In comparison to text warning, implementation of pictorial warning is more effective to reduce/quit smoking and it to increase support for plain packaging..$^{20}$ Pictorial warning also is crucial to deliver its message especially for countries with low literacy rates and for younger smokers. ${ }^{21}$ Larger pictorial health warning are more effective. ${ }^{22}$ In a study done in Sri Lanka, size of pictorial warning of $80 \%$ increases knowledge about the dangers of smoking among both smokers and non-smokers, encourage more conversation with others about the harmof smoking especially among non-smokers and increase quitting among smokers. ${ }^{23}$ In another study in Thailand, $85 \%$ graphic health warning significantly increased fear arousal, and intention not to smoke, among nonsmokers. ${ }^{24}$

The effectiveness of plain cigarette packaging can be proven by post-implementation of plain packaging in certain countries, sales of cigarettes has reduced about 67 million units (sticks) per month, representing around $7.5 \%$ of the market. ${ }^{24}$

Worldwide, Australia was the first country to implement plain packaging on $1^{\text {st }}$ December 2012. ${ }^{15}$ This was followed by France and United Kingdom in 2017, New Zealand, Norway and Ireland in 2018 and Uruguay in 2019. ${ }^{25}$ Laws of plain packaging are passed but awaiting into forcein Romania and Mauritius. ${ }^{26}$ Meanwhile, other countries such as Brazil, Chile, Ecuador, Panama and South Africa, the legislation is still considered by Parliament. Worldwide, Canada was the first country to adopt pictorial warnings in 2011 and since then 118 countries have mandated pictorial warnings. ${ }^{22}$

However, little is known about the implementation of plain pack and pictorial warning in Asia countries and to the researcher's knowledge, there are no reviews done regarding this topic. Hence, this review aims to determine the progress of implementation of plain packaging, implementation of pictorial warning and size of pictorial warning in Asia countries. Implementation of plain packaging and pictorial warning is one of the strategies toassist the countries to achieve the target of WHO of Tobacco End Game.

WHO FCTC and mPOWER Strategy on Plain Packaging and Pictorial W arning

The following des cribes various guidelines on plain packaging and pictorial warning by WHO FCTC and mPOWER. Guidelines for execution of Articles 11 (Packaging and labelling of tobacco products) and Article 13 (Tobacco advertising, promotion and sponsorship) in FCTC includes the implementation of plain packaging of tobacco product. ${ }^{15}$

Under Article 11, it is stated that parties should implement measure to inhibit the use of logos, brand image, colours or promotion on packaging and brand names should be in a uniform colour and font. ${ }^{13}$ This is in line with the implementation of plain packaging. Plain packaging removes all 
marketing elements, including brand, colours, and logos. ${ }^{27}$ All cigarette packaging is mandated be a standardis ed colour and dis plays only a brand name in a standard font style and format. (Fig 1)

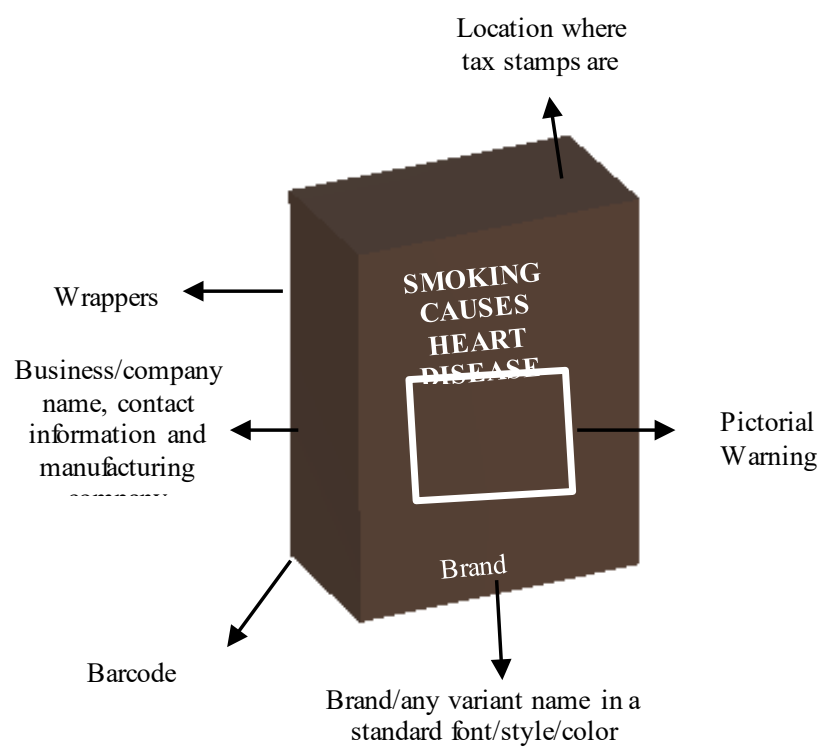

1. Standard colour and finish of colour of outer and inner surfaces of the pack

2. Standard (font, style, font size, location, colour) brand and any variant name

3. Standard (font, style, font size, location, colour) business or company name, contact details and country ofmanufacture

4. Standard materials and adhesives of pack

5. Standard size and shape of the pack

6. Standard type of pack lid and the way it opens

7. Standard pack lining

8. W rappers

9. Standard barcode location on pack

10. Health warnings (text and pictorials, standard size and location on pack, standard time and period of rotation)

11. How and where tax stamps are affixed

Figure 1 Criteria of plain pack ${ }^{15}$

Update on Countries in Asia Regarding Plain Cigarette Packaging Implementation

Since there are many countries in Asia, the res earcher has divided this update in to Central Asia, East Asia, South Asia, South-East Asia and Westem
Asia for convenience ${ }^{28}$ Table 1 shows the implementation of cigarette plain packaging and pictorial warning, and Table 2 shows the details of countries which have implemented plain pack.

Table 1 Plain Cigarette Packaging and Pictorial Warning Policy in Asia

\begin{tabular}{lccc}
\hline \multicolumn{1}{c}{ Country } & $\begin{array}{c}\text { Implementation of } \\
\text { Plain Cigarette Pack } \\
\text { (Yes/No/In } \\
\text { Progress) }\end{array}$ & $\begin{array}{c}\text { Are pictorialwarnings } \\
\text { required on cigarette pack? }\end{array}$ & $\begin{array}{c}\text { Size ofWarning on Cigarette } \\
\text { Pack(front\%/back\%) }\end{array}$ \\
\hline Turkmenistan & No & Central Asia & \\
Kyrgyzstan & No & Yes & $65 / 65$ \\
Kazakhstan & No & Yes & $50 / 50$ \\
Tajikistan & No & Yes & $50 / 50$ \\
Uzbekistan & No & No & $75 / 75$ \\
& & No & $40 / 40$ \\
Nepal & No & South Asia & \\
India & In Progress & Yes & $90 / 90$ \\
Sri Lanka & In Progres & Yes & $85 / 85$ \\
Pakistan & No & Yes & $80 / 80$ \\
Bangladesh & No & Yes & $60 / 60$ \\
Maldives & No & Yes & $50 / 50$ \\
Afghanistan & No & No & $30 / 30^{*}$ \\
Bhutan & No & No & Not specified \\
& & No & Not specified
\end{tabular}




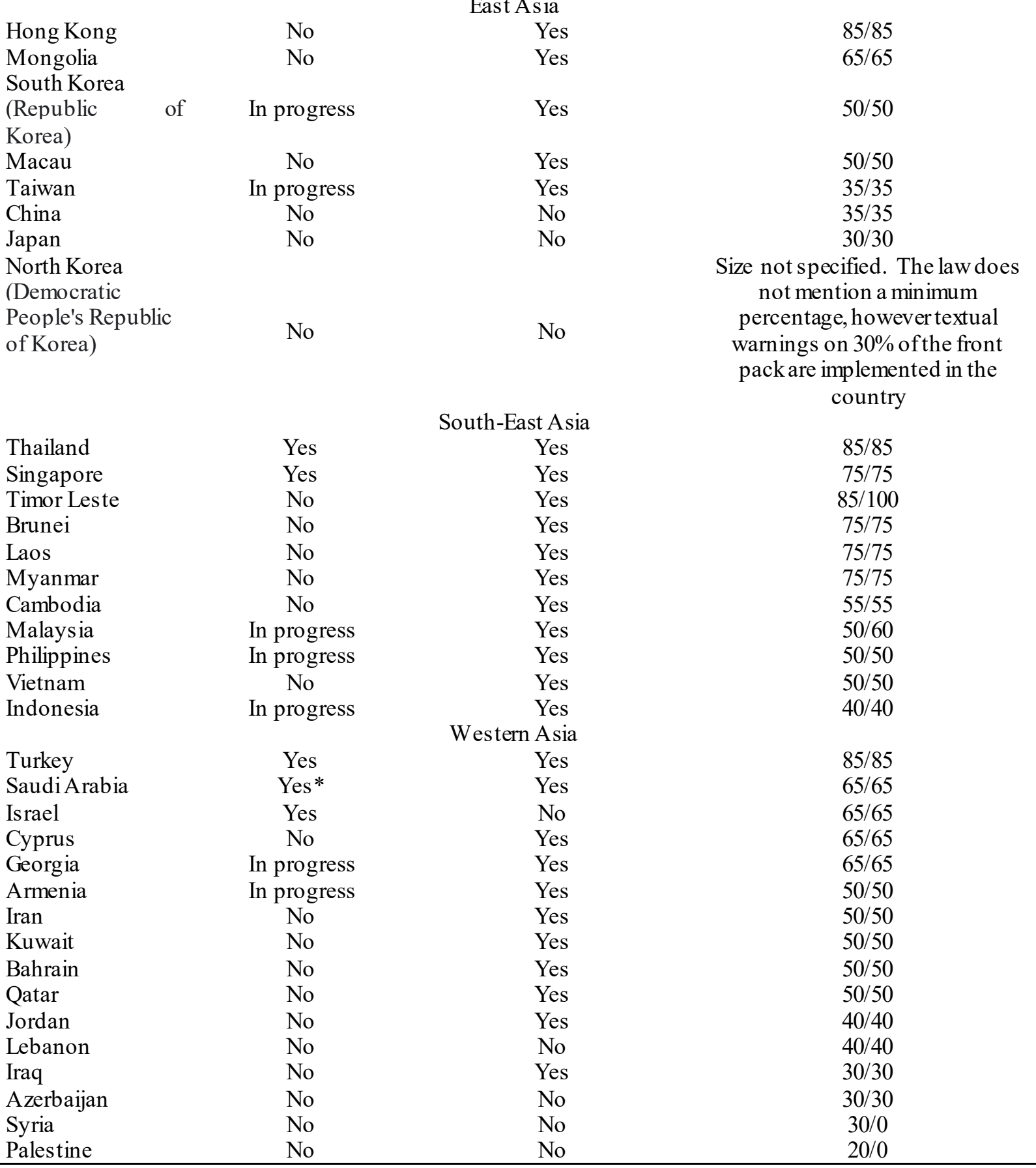

Table 2 Timeline and Challenges for Implementation of Plain Packaging

\begin{tabular}{lcc}
\hline \multicolumn{1}{c}{ Country } & $\begin{array}{c}\text { Date of Implementation of } \\
\text { Plain Pack for Manufacturers }\end{array}$ & $\begin{array}{c}\text { Date of Implementation of } \\
\text { Plain Pack for Retailers }\end{array}$ \\
\hline Thailand & 10 September 2019 & 8 December 2019 \\
Saudi Arabia & 23 August 2019* & $1^{\text {st }}$ January 2020 \\
Turkey & $5^{\text {th }}$ July 2019 & $5^{\text {th }}$ January 2020 \\
Israel & $8^{\text {th }}$ January 2020 & $8^{\text {th }}$ January 2020 \\
Singapore & 1 July 2020 & 1 July 2020 \\
\hline *Date for importers & &
\end{tabular}

Central Asia

None of the countries in Central Asia have implemented plain cigarette pack ${ }^{29-33}$ No literature was found regarding the progress or decision of government to implementation of plain pack in these countries. In the region, only two countries have not 
implemented graphic warning on cigarette pack. ${ }^{29-33}$ However, Tajikistan is in the process of finalizing picture-based warning requirements. ${ }^{34}$ Uzbekistan is inferior from other countries in this region where only text warning is mandated, and the standards is below the WHO requirement (WHO requirement at least $50 \%)^{29-33}$

South Asia

In South Asia, no countries haveimplemented plain packaging. ${ }^{35-42}$ However, certain countries have a greater progress in implementation of plain packaging. In Sri Lanka plain packaging proposal has been approved by cabinet on April 10, 2018. ${ }^{43}$, ${ }^{44}$ In India, amendment was sought in the Cigarettes and Other Tobacco Products Act(COTPA) and in to include plain packaging of tobacco products. Experts in tobacco control fromAustralia and India join forces to produce evidence on the feasibility of plain pack in India. ${ }^{45,46}$

Nepal has one of largest graphic warning in the world where it covers $90 \%$ of tobacco pack which was even larger than Australia (Plain pack in Australia covers $82.5 \%$ of the pack). ${ }^{46,}{ }^{47}$ Many countries in this Asia region taken steps to implement pictorial warning with at least $50 \%$ coverage on cigarette pack size except Maldives (still us es text warning with $30 \%$ coverage), Bhutan (where the tobacco manufacturing is banned, no pictorial warning requirement and no specified warning size for imported products) and Afghanistan (no pictorial warning requirement and no specified warning size). ${ }^{35-42}$ In Afghanistan, in 2016, pictorialwarnings were approved but revised law in 2018 removed the requirement of pictorial label and $50 \%$ coverage. $^{48}$

\section{East Asia}

There are no countries in East Asia which has implemented plain packaging. ${ }^{49-56}$ Only a few countries in this region have made some progress in the pathway of implementation of plain packaging. In Taiwan, a draft (Tobacco Hazards Prevention Act Amendment Bill) was made for plain tobacco packaging in 2017. ${ }^{44}$ In 2019, the ministry in South Korea expressed its intention to implement plain pack.

In comparis on to other countries in this region, countries such as China, North Korea, and Japan are still using text warning on cigarette packs ${ }^{52-59}$ The size of warning is China, Japan and Taiwan does not meet with $50 \%$ requirement of WHO. Surpris ingly, Japan and North Korea is most inferior among all countries where it has not yet implemented pictorial health warning and the size text of warning is $30 \% .^{52-59}$ Evidence from International Tobacco Control project China suggests implementation of pictorial health warning. ${ }^{60}$

\section{South-East Asia}

In this region, there are two countries which have implemented plain packaging. ${ }^{61-71}$ Thailand was the first country in Asia and first middle-income country to implement plain packaging. ${ }^{72}$ The regulations for plain packaging were officially gazette on 14 December 2018 and came into force on 12 September 2019. Specifically, 10 September 2019 was the date of implementation for manufacturers and 8 December 2019 was the date of implementation of retailers. ${ }^{44}$ The regulations apply to all tobacco products and allows a 90-phase phaseout for old stock.

Singapore is the next country in this region to implement plain packaging. In March 2019, the revisions which was made to the Tobacco Act (Controlof Advertisements and Sale) was approved and subsequently the Ministry of Health introduced a subsidiary legislation for implementation of standardized packaging. ${ }^{73}$ The Tobacco Regulations 2019 (Control of Advertisements and Sale) (Appearance, Packaging and Labelling) "SP Regulations") was published on 1 July 2019 came into force on 1 July 2020 for manufacturers and retailers. 44,73

There are some countries in this region which has made some progress in the pathway of implementation of plain packaging. In Malaysia, in February 2019 the Deputy Health Minister expressed the consideration for implementing of plain packaging. ${ }^{25}$ Another source stated that the implementation of plain pack in Malaysia is expected not be earlier than $2025 .{ }^{74}$ In Indonesia, the minister of Health is urging the government to follow Australia footsteps of plain packaging. ${ }^{75} \mathrm{In}$ Philippines, a bill has been filed which entails all the locally produced and imported tobacco products adopt the usage of plain pack. ${ }^{76}$

In comparis on to other Asian regions, South-East Asia is the only region where all the countries have implemented pictorial warning. ${ }^{63-}$ ${ }_{71,77,78}$ Although Timor-Les te havenot implemented plain pack, this country has made incredible progress in the implementation of plain pack. ${ }^{79}$ It has the largest average pictorial warning on tobacco pack $(92.5 \%)$ worldwide and many restrictions of cigarette pack. This includes compuls ory pack color aluminum grey, a brand name sized $15 \%$ (in white color) and brand name may not send any message about tobacco product. This restriction does not comply with the concept of plain packaging since, the brand name can be in a stylized font and the logo is still allowed. All the countries in this region also adhered to WHO standards of $50 \%$ size warning except Indonesia. ${ }^{63-71,77,78}$

Western Asia

In this region, Turkey, Saudi Arabia and Israel has implemented plain packaging. ${ }^{80-95}$ Saudi Arabia is the first country in this region to implement plain 
packaging. In November 2018, the tobacco leg is lation and regulation were updated specifically regarding the tobacco package labelling. ${ }^{96}$ One month later, the Plain Packaging Standards for Tobacco products was approved and applies to all tobacco products. From 23 August 2019 onwards, all the tobacco products imported need to be in plain pack. For retailers, date of implementation of plain tobacco pack was from $11^{\text {st }}$ January 2020 onwards. ${ }^{44}$

In Turkey, in December 2018 the law adopted provisions for tobacco plain pack (includes all to bacco products) and comprehensive regulations were adopted in March 2019. The official date for implementation of plain pack among manufacturers was 5th July 2019 and 5th January 2020 marks the date for retailers. ${ }^{44,74}$ Is rael is another coun try which has implemented plain packaging on this region for all manufacturers and retailers since $8^{\text {th }}$ January 2020. In December 2018, the Parliament legis lation which is related to plain packaging was approved. ${ }^{97}$ Similar to Australia, the color of this packaging is pantone $448 \mathrm{c}$ and text warning which covers $65 \%$ of pack for cigarettes (From01/2020). ${ }^{97}$

Only Georgia and Armenia have made some progress towards implementation of plain pack. In Georgia, the president has signed amending law for the implementation of plain pack in May 2017. ${ }^{44,45}$ It is said to be adopted in July 2017 and implemented by January 2018 but is yet to happen. The Parliament of Armenia has approved a detailed tobacco control law on February 2020 which makes plain packaging compulsory. ${ }^{98}$ In comparison, countries such as Lebanon, Azerbaijan, Syria and Palestine have not mandated pictorial warning and size of warning is les s than $50 \%$ of the cigarette pack in Jordan, Lebanon, Iraq, Azerbaijan, Syria and Palestine. ${ }^{82-94,99-102}$

Challenges for the Implementation of Plain Packaging: Experience fromOtherCountries

Australia was the first country worldwide to implement plain packaging. There were various legal challenges that the country faced by the tobacco industry to prevent and delay the implementation of plain packaging. ${ }^{103,}{ }^{104}$ Legal challenges were also faced by other countries such as United Kingdom, France, Norway and Ireland. ${ }^{104}$ Besides legal challenges, tobacco industry organize various campaigns in countries such as United Kingdom, Australia, Netherlands, and Canada to oppose plain packaging. The theme of these campaigns includes the negative effects of plain packaging which violation of intellectual property rights, induce illicit trade, lack of evidence on effectiveness on plain packaging, decreasing small business and limiting individual choice which creates "nanny state". 105

The latest legal challenge made to World Trade Organization (WTO) was in favour of Australia. ${ }^{103,} 104$ WTO has decided that plain packaging does not violate any intellectual property rights and international trade. In fact, plain pack is neces sary to achieve public health goals. Hence this gives many countries confidenceto implement plain packaging without fear of violating trade or intellectualproperty.

Similarly, the legislation of plain pack was delayed for about 7 years in Thailand due to similar litigation of infringement of trademark and intellectual property rights by tobacco industry. ${ }^{104}$ After WTO favored plain pack, plain packing came into force quickly. Subsequently, this increased implementation of plain packaging in countries in Asia.

\section{CONCLUSION}

In conclusion, only 5 countries have implemented plain cigarette pack in Asia which includes Thailand, Singapore, Turkey, Saudi Arabia, Israel (Western and South-East Asia). Some countries in this region areyet to implement pictorial warning on cigarette pack and implement size of pictorial warning according to WHO requirement. Only region in Asia where all the countries have implemented pictorial warning on plain pack is South-East Asia. Timor Leste in South-East Asia region has the largest pictorial warning the world. Although some countries in Asia have not implemented plain pack, implementation of larger pictorial warning serve as a pathway for implementation of plain packaging.

All countries including countries in Asia should target to implement standardized pack, pictorial warning on cigarette pack and size of pictorial warning according to WHO requirements. Countries who have yet to implement plain pack and pictorial warning should collaborate with other counties to ensure that they produce wordings for legislation for theseplain pack and pictorial warning with negligible loopholes. Other resources which can be used by these countries include the Campaign for Tobacco-Free Kids' Plain Packaging Toolkit, and WHO's report on the evidence, design and implementation of tobacco product plain packaging.

\section{ACKNOWLEDGEMENTS}

We would like to acknowledge National University of Malaysia for grant (FF-2020-057).

\section{CONFLICT OF INTEREST STATEMENT}

The authors declare that they have no conflict of interest.

\section{REFERENCES}

1. World Health Organization. Tobacco, 2020. Available from: https://www.who.int/news-room/factsheets/detail/tobacco. 
2. Roh S. Scientific Evidence for the Addictiveness of Tobacco and Smoking Cessation in Tobacco Litigation. Journal of Preventive Medicine and Public Health. 2018;51(1):1.

3. West R. Tobacco smoking: Health impact, prevalence, correlates and interventions. Psychology \& health. 2017;32(8):1018-36.

4. Centers of Dis ease Control and Prevention. Health Effects of Cigarette Smoking, 2018. Available from: https://www.cdc.gov/tobacco/data statisti cs/fact_sheets/health_effects/effects_cig_s moking/index.htm.

5. World Health Organization. Tobacco Use in Adolescence, 2016. Available from: http://www.euro.who.int/_data/assets/pdf file/0016/303532/HBSC-

No.7 factsheet Tobacco.pdf?ua $=1$.

6. Demis sie Z, Jones SE, Clayton HB, King BA. Adolescent risk behaviors and use of electronic vapor products and cigarettes. Pediatrics . 2017; 139(2):e20162921.

7. Badiani A, Boden JM, De Pirro S, Fergusson DM, Horwood LJ, Harold GT. Tobacco smoking and cannabis use in a longitudinal birth cohort: evidence of reciprocal causal relationships. Drug and alcoholdependence. 2015;150:69-76.

8. Weinberger AH, Platt J, Es an H, Galea S, Erlich D, Goodwin RD. Cigarette smoking is associated with increased risk of substance use disorder relapse: a nationally representative, prospective longitudinal investigation. The Journal of clinical psychiatry. 2017;78(2):e152.

9. World Health Organization. The WHO Framework Convention on Tobacco Control: an overview, 2015. Available from:

https://www.who.int/fctc/about/WHO_FC TC_summary_January2015.pdf?ua $=1$.

10. World Health Organization. Parties to the WHOFramework Convention on Tobacco Control, 2020. Available from: https://www.who.int/fctc/cop/en/.

11. World Health Organization. Role of the WHO FCTC in legal challenges, 2020 Available from: https://untobaccocontrol.org/kh/legalchallenges/role-of-the-who-fctc/\#intro.

12. World Health Organization. Tobacco Free Initiaves- mPOWER measures, 2020. Available from: http://www.emro.who.int/tfi/mpower/inde x.html.

13. World Health Organization. Plain packaging of tobacco products: evidence, design and implementation, 2016. Available from: https://apps.who.int/iris/handle/10665/207 478.

14. World Health Organization. WHO FCTC Health Warnings Database, 2020. Available from: https://www.who.int/tobacco/healthwarnin gsdatabase/en/.

15. World Health Organization. Tobacco plain packaging: Global status update: World Health Organization, 2018. Available from:

https://www.who.int/publications/i/item/ WHO-NMH-PND-NAC-18.9.

16. Lilic N, Stretton M, Prakash M. How effective is the plain packaging of tobacco policy on rates of intention to quit smoking and changing attitudes to smoking? ANZ journal of surgery. 2018;88(9):825-30.

17. Webb H, Jones BM, McNeill K, Lim L, Frain AJ, O'Brien KJ, et al. Smoke signals: The decline of brand identity predicts reduced smoking behaviour following the introduction of plain packaging. Addictive Behaviors Reports. 2017;5:49-55.

18. Sinsuwarn N, Rattanakasamsuk K. Tobacco Packaging as Communication Tool: The Effectiveness of Tobacco Plain Packaging on Young People's Perception. วารสาร วิชาการ มนุษยศาสตร์ และ สังคมศาสตร์ มหาวิทยาลัย บูรพา. 2020;28(1):98-119.

19. Gallopel-Morvan K, Hoek J, Rieunier S. Do Plain Packaging and Pictorial W arnings Affect Smokers' and Non-Smokers' Behavioral Intentions? Journal of Consumer Affairs . 2018;52(1):5-34.

20. Agaku IT, Filippidis FT, Vardavas CI. Effectiveness of text versus pictorial health warning labels and predictors of support for plain packaging of tobacco products within the European Union. European addiction research. 2015;21(1):47-52.

21. World Health Organization. WHO Report on the Global Tobacco Epidemic, 2008: The MPOWER package.Geneva, 2008. Available from: https://apps.who.int/iris/handle/10665/438 18.

22. Canadian Cancer Society. Cigarette Package Health Warnings, 2018. Available from:

https://www.tobaccofreekids.org/assets/gl obal/pdfs/en/WL status report en.pdf.

23. Zawahir S, Madhushika M, Yong H-H. Effectiveness of pictorial health warnings on cigarette packs among adults in a rural Sri Lankan community. Tobacco Induced Dis eas es. 2018;16(1).

24. Sirichotiratana N, Sujirarat D, Sompopcharoen M, Viwatwongkas em C, 
Satitvipawee P, Auemaneekul N, et al. Effectiveness of $85 \%$ graphic health warning on cigarette packs on smoking behaviours of Thai teenagers. Tobacco Induced Dis eases. 2018;16(1).

25. Canadian Cancer Society. Plain Packaging - International Overview, 2019.

26. Canadian Cancer Society. International developments in plain packaging, 2019. Available from: https://www.cancervic.org.au/plainfacts/ti melineandinternationaldevelopments.

27. Vardavas C, Filippidis FT, Ward B, Faure M, Jimenez-Ruiz C, Gratziou C, et al. Plain packaging of tobacco products in the European Union: an EU success story? : Eur Respiratory Soc, 2017.

28. Amber Pariona. What Are The Five Regions of Asia? 2020. Available from: https://www.worldatlas.com/articles/thefour-regions-of

asia.html\#: : :text $=$ Asia $\% 20$ can $\% 20$ be $\% 20$ divided $\% 20$ into,Southeast $\% 20$ Asia $\% 2 \mathrm{C} \%$ 20and $\% 20$ W estern $\% 20$ Asia.

29. World Health Organization. WHO report on the global tobacco epidemic-Country Profile Kyrgyzstan, 2019. Available from: https://www.who.int/tobacco/surveillance/ policy/country_profile/kgz.pdf?ua=1.

30. World Health Organization. WHO report on the global tobacco epidemic-Country Profile Turkmenistan, 2019. Available from:

https:/www.who.int/tobacco/surveillance/ policy/country profile/tkm.pdf?ua $=1$.

31. World Health Organization. WHO report on the global tobacco epidemic-Country Profile Kazakhstan, 2019. Available from https://www.who.int/tobacco/surveillance/ policy/country profile/kaz.pdf.

32. World Health Organization. WHO report on the global tobacco epidemic-Country Profile Uzbekistan, 2019. Available from: https://www.who.int/tobacco/surveillance/ policy/country_profile/uzb.pdf.

33. World Health Organization. WHO report on the global tobacco epidemic-Country Profile Tajikistan, 2019. Available from: https://www.who.int/tobacco/surveillance/ policy/country profile/tjk.pdf.

34. The Cancer Council Victoria. Health warnings used in other countries, 2019. Available from: https://www.tobaccoinaustralia.org.au/cha pter-12-tobacco-products/attachment-121-health-warnings/12a-2-health-warningsused-in-other-countries.

35. World Health Organization. WHO report on the global tobacco epidemic-Country Profile Afganistan, 2019. Available from: https://www.who.int/tobacco/surveillance/ policy/country profile/afg.pdf?ua $=1$.

36. World Health Organization. WHO report on the global tobacco epidemic-Country Profile Bangladesh, 2019. Available from https://www.who.int/tobacco/surveillance/ policy/country profile/bgd.pdf?ua=1.

37. World Health Organization. WHO report on the global tobacco epidemic-Country Profile Bhutan, 2019. Available from: https://www.who.int/tobacco/surveillance/ policy/country_profile/btn.pdf.

38. World Health Organization. WHO report on the global tobacco epidemic-Country Profile India, 2019. Available from: https://www.who.int/tobacco/surveillance/ policy/country profile/ind.pdf.

39. World Health Organization. WHO report on the global tobacco epidemic-Country Profile Maldives, 2019. Available from: https://www.who.int/tobacco/surveillance/ policy/country profile/mdv.pdf.

40. World Health Organization. WHO report on the global tobacco epidemic-Country Profile Nepal, 2019. Available from: https://www.who.int/tobacco/surveillance/ policy/country profile/npl.pdf.

41. World Health Organization. WHO report on the global tobacco epidemic-Country Profile Pakistan, 2019. Available from: https://www.who.int/tobacco/surveillance/ policy/country profile/pak.pdf.

42. World Health Organization. WHO report on the global tobacco epidemic-Country Profile Sri Lanka, 2019. Available from: https:/www.who.int/tobacco/surveillance/ policy/country_profile/lka.pdf.

43. World Health Organization. Tobacco control including WHO MPOWER package in SEAR Member States Evaluation Report, 2018.

44. Campaign for Tobacco Free Kids. Standardized or plain tobacco packaging international developments, 2020. Available from: https://www.tobaccofreekids.org/assets/gl obal/pdfs/en/standardized packaging_dev elopments_en.pdf.

45. Canadian Cancer Society. Cigarette Package Health Warning, 2018. Available from:

https://www.tobaccofreekids.org/assets/gl obal/pdfs/en/WL_status_report_en.pdf.

46. Yadav A, Nazar GP, Rawal T, Arora M, Webster P, Grills N. Plain packaging of tobacco products: the logical next step for tobacco control policy in India. BMJ global health. 2018;3(5).

47. Southeast Asia Tobacco Control Allince. Nepal implements $90 \%$ graphic health 
warnings on tobacco packs, strictest in the world, 2015. Available from: https://seatca.org/nepal-implements-90per-cent-graphic-health-warnings-ontobacco-packs-s trictest-in-the-world/.

48. Campaign for Tobacco-FreeKids. Tobacco Control Laws-Legislation by Country: Afganistan (Health Warning/Message Features), 2020. Available from: https://www.tobaccocontrollaws.org/legisl ation/country/afghanistan/pl-healthwarnings.

49. Campaign for Tobacco-FreeKids. Tobacco Control Laws-Legislation by Country: Macau (Other Packaging and Labeling Requirements), 2020. Available from: https:/www.tobaccocontrollaws.org/legisl ation/country/macau-(china)/pl-other-reqs.

50. Campaign for Tobacco-Free Kids. Tobacco Control Laws-Legislation by Country: Taiwan (Other Packaging and Labeling Requirements), 2020. Available from: https:/www.tobaccocontrollaws.org/legisl ation/country/taiwan/pl-other-reqs.

51. Campaign for Tobacco-Free Kids. Tobacco Control Laws-Legislation by Country:Hong Kong(Other Packaging and Labeling Requirements), 2020. Available from:

https:/www.tobaccocontrollaws.org/legisl ation/country/hong-kong-(china)/pl-otherreqs.

52. World Health Organization. WHO report on the global tobacco epidemic-Country Profile China, 2019. Available from: https://www.who.int/tobacco/surveillance/ policy/country_profile/chn.pdf.

53. World Health Organization. WHO report on the global tobacco epidemic-Country Profile Democratic People Republic of Korea, 2019. Available from: https://www.who.int/tobacco/surveillance/ policy/country profile/prk.pdf.

54. World Health Organization. WHO report on the global tobacco epidemic-Country Profile Japan, 2019. Available from: https://www.who.int/tobacco/surveillance/ policy/country profile/jpn.pdf.

55. World Health Organization. WHO report on the global tobacco epidemic- Country Profile Mongolia, 2019. Available from: https://www.who.int/tobacco/surveillance/ policy/country_profile/mng.pdf.

56. World Health Organization. WHO report on the global tobacco epidemic-Country Profile Republic of Korea, 2019. Available from:

https://www.who.int/tobacco/surveillance/ policy/country_profile/kor.pdf.
57. Campaign for Tobacco-FreeKids. Tobacco Control Laws-Legislation by Country: Macau (Health Warnings/Messages Features), 2020. Available from: https://www.tobaccocontrollaws.org/legisl ation/country/macau-(china)/pl-healthwarnings.

58. Campaign for Tobacco-FreeKids. Tobacco Control Laws-Legislation by Country: Taiwan (Health Warnings/Messages Features), 2020. Available from: https://www.tobaccocontrollaws.org/legisl ation/country/taiwan/pl-health-warnings.

59. Campaign for Tobacco-FreeKids. Tobacco Control Laws-Legislation by Country:Hong Kong (Health Warnings/Messages Features), 2020. Available from: https://www.tobaccocontrollaws.org/legisl ation/country/hong-kong-(china)/plhealth-warnings.

60. World Health Organization Westem Pacific Region UoW, ITC Project, ThinkTank Research Center for Health Development. Tobacco health warnings in China: evidence of effectiveness and implications for action. Geneva 27, Switzerland, 2014.

61. Campaign for Tobacco-FreeKids. Tobacco Control Laws-Legislation by Country: Myanmar (Other Packaging and Labeling Requirements), 2020. Available from: https://www.tobaccocontrollaws.org/legisl ation/country/myanmar/pl-other-reqs.

62. Campaign for Tobacco-Free Kids. Tobacco Control Laws-Legislation by Country: Singapore (Other Packaging and Labeling Requirements), 2020. Available from: https://www.tobaccocontrollaws.org/legisl ation/country/singapore/pl-other-reqs.

63. World Health Organization. WHO report on the global tobacco epidemic-Country Profile Brunei, 2019. Available from: https://www.who.int/tobacco/surveillance/ policy/country_profile/brn.pdf?ua $=1$.

64. World Health Organization. WHO report on the global tobacco epidemic-Country Profile Cambodia, 2019. Available from: https://www.who.int/tobacco/surveillance/ policy/country_profile/khm.pdf.

65. World Health Organization. WHO report on the global tobacco epidemic-Country Profile Indonesia, 2019. Available from: https://www.who.int/tobacco/surveillance/ policy/country profile/idn.pdf.

66. World Health Organization. WHO report on the global tobacco epidemic-Country Profile Laos, 2019. Available from: https://www.who.int/tobacco/surveillance/ policy/country_profile/lao.pdf?ua=1. 
67. World Health Organization. WHO report on the global tobacco epidemic-Country Profile Malaysia, 2019. Available from: https:/www.who.int/tobacco/surveillance/ policy/country_profile/mys.pdf.

68. World Health Organization. WHO report on the global tobacco epidemic-Country Profile Philippines, 2019. Available from: https:/www.who.int/tobacco/surveillance/ policy/country_profile/phl.pdf.

69. World Health Organization. WHO report on the global tobacco epidemic-Country Profile Thaliand, 2019. Available from: https:/www.who.int/tobacco/surveillance/ policy/country_profile/tha.pdf.

70. World Health Organization. WHO report on the global tobacco epidemic-Country Profile Timor Leste, 2019. Available from: https://www.who.int/tobacco/surveillance/ policy/country profile/tls.pdf?ua $=1$.

71. World Health Organization. WHO report on the global tobacco epidemic-Country Profile Vietnam, 2019. Available from: https://www.who.int/tobacco/surveillance/ policy/country_profile/vnm.pdf?ua $=1$.

72. WHO Framework Convention of Tobacco Control. Thailand: the plain packaging legislation enters into force, 2016. Available from: https://untobaccocontrol.org/impldb/thaila nd-the-plain-packaging-legislation-entersinto-force/.

73. Ministry ofHealth Singapore. Standardised packaging \& enlarged graphic health warnings, 2019. Available from: https://www.moh.gov.sg/news-

highlights/details/standardised-packagingenlarged-graphic-health-warningsmandatory-for-all-tobacco-products-ins in gapore-from-1-july-2020.

74. Global Advertising Lawyers Alliance. Plain Packaging Update, 2020.

75. Southeast Asia Tobacco Control Allince. Indonesia: Plain cigarette packaging to put smokers off, ministry hopes, 2016. Available from: https://seatca.org/plaincigarette-packaging-to-put-smokers-offminis try-hopes/.

76. Southeast Asia Tobacco Control Allince. Philippines: Pimentel files bill seeking to require cigarettemanufacturers to use plain packaging, 2019. Available from: https://seatca.org/pimentel-files-bills eeking-to-require-cigarettemanufacturers-to-use-plain-packaging/.

77. Campaign for Tobacco-FreeKids. Tobacco Control Laws-Legislation by Country: Myanmar (Health Warnings/Messages Features), 2020. Available from: https://www.tobaccocontrollaws.org/legisl ation/country/myanmar/pl-healthwarnings .

78. Campaign for Tobacco-Free Kids. Tobacco Control Laws-Legislation by Country: Singapore (Health Warnings/Messages Features), 2020. Available from: https://www.tobaccocontrollaws.org/legisl ation/country/singapore/pl-healthwarnings.

79. WHO Framework Convention of Tobacco Control. Timor-Leste: pictorial warnings required on tobacco packages and progress is made towards plain packaging, 2016 Available from: https://untobaccocontrol.org/impldb/timor -leste-pictorial-warnings-required-ontobacco-packages-and-progress-is-madetowards-plain-packaging/.

80. Campaign for Tobacco-Free Kids. Tobacco Control Laws-Legislation by Country: Israel (Other Packaging and Labeling Requirements), 2020. Available from: https://www.tobaccocontrollaws.org/legisl ation/country/israel/pl-other-reqs.

81. Campaign for Tobacco-Free Kids. Tobacco Control Laws-Legislation by Country: Turkey (Other Packaging and Labeling Requirements), 2020. Available from: https://www.tobaccocontrollaws.org/legisl ation/country/turkey/pl-other-reqs.

82. World Health Organization. WHO report on the global tobacco epidemic-Country Profile Armenia, 2019. Available from: https://www.who.int/tobacco/surveillance/ policy/country profile/arm.pdf?ua $=1$.

83. 83. World Health Organization. WHO report on the global tobacco epidemic-Country Profile Azerbaijan, 2019. Available from: https://www.who.int/tobacco/surveillance/ policy/country_profile/aze.pdf.

84. World Health Organization. WHO report on the global tobacco epidemic-Country Profile Bahrain, 2019. Available from: https://www.who.int/tobacco/surveillance/ policy/country_profile/bhr.pdf?ua $=1$.

85. World Health Organization. WHO report on the global tobacco epidemic-Country Profile Cyprus, 2019. Available from: https://www.who.int/tobacco/surveillance/ policy/country profile/cyp.pdf.

86. 86. World Health Organization. WHO report on the global tobacco epidemic-Country Profile Georgia, 2019. Available from: https://www.who.int/tobacco/surveillance/ policy/country_profile/geo.pdf?ua $=1$.

87. World Health Organization. WHO report on the global tobacco epidemic-Country Profile Iran, 2019. Available from: 
https:/www.who.int/tobacco/surveillance/ policy/country profile/irn.pdf?ua $=1$.

88. World Health Organization. WHO report on the global tobacco epidemic-Country Profile Iraq, 2019. Available from: https:/www.who.int/tobacco/surveillance/ policy/country_profile/irq.pdf.

89. World Health Organization. WHO report on the global tobacco epidemic-Country Profile Jordan, 2019. Available from: https://www.who.int/tobacco/surveillance/ policy/country_profile/jor.pdf.

90. World Health Organization. WHO report on the global tobacco epidemic-Country Profile Kuwait, 2019. Available from: https://www.who.int/tobacco/surveillance/ policy/country_profile/kwt.pdf?ua $=1$.

91. World Health Organization. WHO report on the global tobacco epidemic-Country Profile Lebonan, 2019. Available from: https://www.who.int/tobacco/surveillance/ policy/country profile/lbn.pdf.

92. World Health Organization. WHO report on the global tobacco epidemic-Country Profile Qatar, 2019. Available from: https:/www.who.int/tobacco/surveillance/ policy/country_profile/qat.pdf?ua $=1$.

93. World Health Organization. WHO report on the global tobacco epidemic-Country Profile Saudi Arabia, 2019. Available from:

https://www.who.int/tobacco/surveillance/ policy/country_profile/sau.pdf.

94. World Health Organization. WHO report on the global tobacco epidemic-Country Profile Syria, 2019. Available from: https://www.who.int/tobacco/surveillance/ policy/country_profile/syr.pdf.

95. Campaign for Tobacco-Free Kids. Tobacco Control Laws-Legislation by Country: Palestine (Other Packaging and Labeling Requirements), 2020. Available from: https://www.tobaccocontrollaws.org/legisl ation/country/palestine/pl-other-reqs.

96. WHO Framework Convention of Tobacco Control. Saudi Arabia adopts plain packaging on tobacco products, 2016. Available from: https://untobaccocontrol.org/impldb/saudi arabia-adopts-plain-packaging-ontobacco-products/.
97. Rosen L, Kis lev S, Bar-Zeev Y, Levine H. Historic tobacco legislation in Israel: a moment to celebrate. Israel Journal of Health Policy Res earch. 2020;9:1-7.

98. The Union. Armenian Parliament approves new tobacco control law, 2020. Available from: https://theunion.org/news/armenianparliament-approves-new-tobacco-controllaw.

99. Campaign for Tobacco-Free Kids. Tobacco ControlLaws-Legis lation by Country: Iraq (Health Warning/Message Features), 2020. Available from: https://www.tobaccocontrollaws.org/legisl ation/country/iraq/pl-health-warnings.

100. Campaign for Tobacco-Free Kids. Tobacco Control Laws-Legislation by Country: Israel(Health Warning/Message Features), 2020. Available from: https://www.tobaccocontrollaws.org/legisl ation/country/israel/pl-health-warnings.

101. Campaign for Tobacco-Free Kids. Tobacco Control Laws-Legislation by Country: Palestine (Health Warning/Message Features), 2020. Available from: https://www.tobaccocontrollaws.org/legisl ation/country/palestine/pl-healthwarnings .

102. Campaign for Tobacco-Free Kids. Tobacco Control Laws-Legislation by Country: Turkey (Health Warning/Message Features), 2020. Available from: https://www.tobaccocontrollaws.org/legisl ation/country/turkey/pl-health-warnings.

103. O'Dowd A. Latest legal challenge to tobacco plain packaging is rejected by the World Trade Organization. BMJ: British Medical Journal(Online). 2018;361.

104. Cohen JE, Zhou S, Goodchild M, Allwright S. Plain packaging of tobacco products: Lessons for the next round of implementing countries. Tobacco Induced Dis eas es. 2020; 18.

105. MacKenzie R, Mathers A, Hawkins B, Eckhardt J, Smith J. The tobacco industry's challenges to standardised packaging: A comparative analysis of is sue framing in public relations campaigns in four countries. Health Policy. 2018; 122(9):1001-11. 